\title{
Distinction Awards: the system in England and Wales
}

The Guide to the NHS Consultants' Distinction Award Scheme (EL(97)69), dated 14 November 1997, describes the current procedures as agreed by the Advisory Committee on Distinction Awards (ACDA). This guide describes the arrangements for $B, A$ and $A+$ awards.

The College has always considered that the Distinction Awards system should be fair and open. Any College member who is eligible for an Award and believes that he or she has been overlooked for any reason should contact their Regional Adviser for Distinction Awards (see Appendix) or the President. It should be noted that these Advisers have quite separate responsibilities from the College's Regional Advisers for Postgraduate Education.

\section{Criteria for awards}

There are no formal criteria for awards, but general guidelines are set out in Annex $A$ of the Guide referred to above. Every trust is provided with a copy and this can be consulted by members. The Guide states that to warrant consideration for an award, the various awards committees look for performance over and above what is normally expected in respect of service to patients, teaching and the management and development of the service. Principally, they will be looking for the following qualities:

(a) Professional excellence and recognition of leadership.

(b) Research, innovation and improvement in the service. The expectations may vary for different groups, health authority or trust, teaching and honorary, and will relate to their differing opportunities.

(c) Outstanding administrative or management effort, including those who effectively implement innovations involving activities, often of national significance, which will again be related to opportunity and normal expectations. For example, there will be exceptions for honorary National Health Service (NHS) contract holders (e.g. academics and research workers staff whose duties include a smaller NHS management content.

(d) An outstanding contribution to other forms of service development such as clinical audit. (e) Teaching and training; for example, special effort to train junior staff, or take an active part in undergraduate or postgraduate medical education (including establishment of short-term national or overseas training links), especially if undertaken in addition to ordinary duties. Contributions to the training of other NHS staff and also to public education and health promotion will also be relevant.

(f) Outstanding and sustained service to the NHS in an exceptionally hard-pressed post.

For the small number of awards available at A and $A+$ level, a very high standard is required. Awards might be recommended for those who are evident leaders in a clinical or scientific field, those with special clinical managerial skills, those who contribute new ideas of proven worth, those who effectively implement innovations, those who are generally accepted as leaders of their profession in their region and the country as a whole and those with a national or international reputation.

\section{Eligibility for awards}

The full criteria for eligibility are set out in the Guide.

Practitioners must hold a medical or dental qualification, be fully registered and be employed as a consultant (or honorary consultant) by a health authority or health board, a special health authority or an NHS trust, the Special Hospitals Service Authority, the Health Education Authority, the Department of Health, the Welsh Health Common Services Authority.

Consultants in NHS trusts will continue to be eligible for Distinction Awards whether they remain subject to nationally determined terms and conditions of service or to terms agreed between them and the individual trust.

Consultants employed in full-time general management positions (chief executives or general managers) are not eligible. Locum consultants are not eligible.

\section{Age limit}

The age limit for granting B, A and A+ awards is 62. Practitioners who reach age 62 during the 
awards round (1 October-30 September) will remain eligible for higher awards.

\section{How the system works}

There are three ways in which Distinction Award recommendations are fed into the decisionmaking system.

(a) recommendations from the regional awards committees (see below). This encompasses all specialities represented in the region;

(b) recommendations through the medical Royal Colleges;

(c) recommendations made directly to the ACDA Chairman or the Chairman of the relevant regional awards committee or higher awards committee on behalf of self or colleague.

Chairman of the ACDA: Sir William Reid Medical Director of the ACDA: Sir Christopher Paine

\section{Regional awards committees}

The regional awards committees (RACs), which are sub-committees of the ACDA, are based on the eight English health regions with a separate sub-committee for Wales. Six of the English regions are each sub-divided into two committees. The RACs, chaired by a regional chairman, with a professional vice-chairman, are responsible for the input from the medical profession.

Membership is drawn from among $A$ and $A+$. and occasionally $B$, award holders within the region. There is employer representation on each RAC. The recommendations from each RAC, in ranked order, are submitted to the ACDA. The ACDA Chairman and Medical Director consider each recommendation and visit each region to discuss these with the RAC. The ACDA Chairman and Medical Director then prepare a final list of recommendations for each region for consideration and decision by the ACDA.

\section{Review of awards}

All new or increased awards allocated from the 1989 awards round onwards are subject to review to ensure that the award is still merited. The review is undertaken during the fourth year of receipt of an award, so that any decision to downgrade or withdraw an award will be effective five years from the date on which the award was first paid. $B$ and $A$ awards will be reviewed by the appropriate RAC and $A+$ awards will be reviewed by the ACDA.

\section{Royal College of Psychiatrists' system England and Wales}

The President appoints a senior psychiatrist from A+, A, and occasionally B, award holders, in each region to become the College's Regional Adviser for Distinction Awards (RADA). Each adviser calls an annual meeting to which all existing award holders in the speciality are invited. Existing award holders are able to advise the RADA on recommendations for their own, but not any higher level of award. B award holders, for example, can advise on non-award holders put forward for the B award, but do not do so for A awards and are not present at these discussions.

The College's RADA has a list of all current consultant psychiatrists in the region. This is the basic working list on which decisions are based. Inaccuracies in these lists occur, particularly in the case of new appointments, or where there are split appointments between regions. The College sends a list of any inaccuracies it detects to the ACDA each year.

The President calls an annual meeting, divided into $A$ and $B$ sections, at which Honorary Officers of the College, RADAs, Chairmen of Divisions and Faculties (if they hold the relevant awards) meet to prepare the College recommendations. If a Chairman of a Faculty does not hold the relevant award, then an alternative senior specialist is identified by the President.

Participants at this meeting are circulated with lists of all consultant psychiatrists in England and Wales divided by speciality. There is a quota of A and B Merit Awards and the purpose of the meeting is to consider all consultant psychiatrists and prioritise the recommendations so that the appropriate number of recommendations is put forward to the ACDA in rank order.

At the meeting, the President reads out each name. If any two members of the Committee support a name then it is placed on the provisional list of recommendations. Once the lists of all specialities have been read out, the member who has nominated an individual may speak on behalf of the nominee for not more than two minutes. A ballot paper, with spaces just exceeding the quota determined by the ACDA. is circulated and each committee member completes this with no consultation. The votes are then added up, the results announced and forwarded to the Chairman of the ACDA, together with the citation forms which have been prepared in advance of the meeting. They are then considered by the ACDA, together with other recommendations from the other sources.

\section{Timetable}

Late November ACDA Chairman writes to Royal Colleges for nominations. Nominal roll of practitioners eligible for awards sent to the College. The College circulates nominal 
roll to members of the Distinction Awards Committee.

Mid-December President chairs annual meeting with awards advisers and Honorary Officers to prepare College recommendations.

Early January Recommendations sent to ACDA.

April-July ACDA Chairman and ViceChairman visit the regions to discuss their nominations and those from other sources.

September Recommendations drawn up for consideration at the annual meeting of the ACDA.

October Annual meeting of the ACDA which the President attends.

\section{Action by members}

Members of the College who are eligible for an award should:

(a) Check that their name is on the regional list and that the information is correct. The employer will have been notified automatically and a copy of the nominal roll is sent to each trust.

(b) Prepare a curriculum vitae for the RAC when requested. The relevant forms are available from this Committee.

(c) Supply a curriculum vitae to the Chairman of their College Faculty or the College's RADA.

\section{Discretionary points}

Discretionary points are decided under a separate arrangement. The College is not involved in this process. Some trusts approach the College seeking professional input, but they are not obliged to do so. The College refers all such queries to the College's RADAs.

It is not essential that a consultant should hold the full allocation of five discretionary points, or indeed any at all, to be considered for a distinction award, though usually they will be in receipt of at least some.

\section{Appendix Regional Advisers for Distinction Awards}

East Anglia

Mersey

Northern

Northern Ireland

North-East Thames

North-West Thames

North Western

Oxford

South-East Thames

South-West Thames

South Western

Trent

Wales

Wessex

West Midlands

Yorkshire
Dr G. E. Berrios

Dr J. Higgins

Dr A. Kerr

Professor D. King

Dr N. Graham

Professor P. Tyrer

Professor F. Creed

Dr R. Mayou

Professor A. Cox

Professor S. Hollins

Dr J. A. O. Russell

Dr R. Palmer

Professor W. I. Fraser

Dr M. A. Rowton-Lee

Dr T. Betts

Professor A. C. P. Sims
Vanessa Cameron. The Secretary, Royal College of Psychiatrists, 17 Belgrave Square, London SWIX 8PG

Enquiries, including those to the Chairman of the ACDA, should be addressed to the ACDA Secretariat, NHS Management Executive, Room 2N35D, Quarry House, Quarry Hill, Leeds LS2 7UE. Tel: 01132546087. 